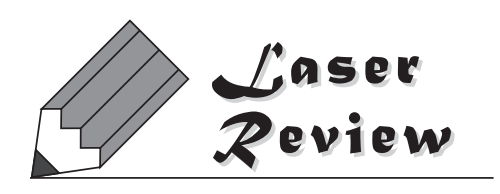

\title{
フォトニック結晶ナノ共振器ラマンシリコンレーザー
}

\author{
高橋 和 $^{1}$, 乾 善貴 ${ }^{2}$, 浅野 卓 $^{2}$, 野田 進 ${ }^{2}$ \\ 大阪府立大学 21 世紀科学研究機構 ( $\bar{T} 599-8570$ 大阪府堺市中区学園町1-2) \\ 2京都大学 工学研究科 ( $7615-8510$ 京都府京都市西京区京都大学桂)
}

\section{Raman Silicon Laser Using a Photonic Crystal Nanocavity}

\author{
Yasushi TAKAHASHI, ${ }^{1}$ Yoshitaka INUI, ${ }^{2}$ Takashi ASANO, ${ }^{2}$ and Susumu NODA ${ }^{2}$ \\ 'Osaka Prefecture University, 1-2 Gakuencho, Nakaku, Sakai, Osaka 599-8570 \\ ${ }^{2}$ Kyoto University, Kyotodaigakukatsura, Nishikyoku, Kyoto 615-8510
}

(Received November 6, 2013)

\begin{abstract}
Continuous-wave Raman lasing in the silicon rib waveguide was presented in 2005 as the long-awaited silicon laser. However, the required miniaturization to micrometer dimensions and reduction of the threshold to microwatt energies had not advanced sufficiently since the initial discovery. Such lasers have remained limited to $\mathrm{cm}$-sized cavities with thresholds higher than $20 \mathrm{~mW}$, even with the assistance of reverse-biased p-i-n diodes. In this paper, we have report a continuous-wave Raman silicon laser using a photonic-crystal high-quality $(Q)$ factor nanocavity without any $\mathrm{p}$-i-n diode, which yield a device with a cavity size of less than 10 micrometers and an ultralow threshold of $1 \mu \mathrm{W}$. We contrived a unique design of the high- $Q$ nanocavity to bring out the tremendous potential derived from the simple principle that light-matter interactions are proportional to the ratio of $Q$ and the volume of the cavity. Our demonstration represents a milestone in solid-state optics and may pave the way to the construction of practical silicon lasers and amplifiers for large-scale-integration in photonic circuits.
\end{abstract}

Key Words: Silicon laser, Raman scattering, Photonic crystal, High- $Q$ nanocavity

\section{1.はじめに}

光技術の源泉となるレーザー光をシリコンから生み出 すことは, シリコンフォトニクス分野の重要な課題とさ 机てきた. Fig. 1に示すようにシリコンは間接遷移型半 導体であり, バンド間遷移による発光確率を高くするこ とは物理的に困難である1)。ガリウムヒ素などのIII - V 属元素を用いた半導体レーザーの産業化が進められ始め た1970年代以降，シリコンでレーザーを作るために様々

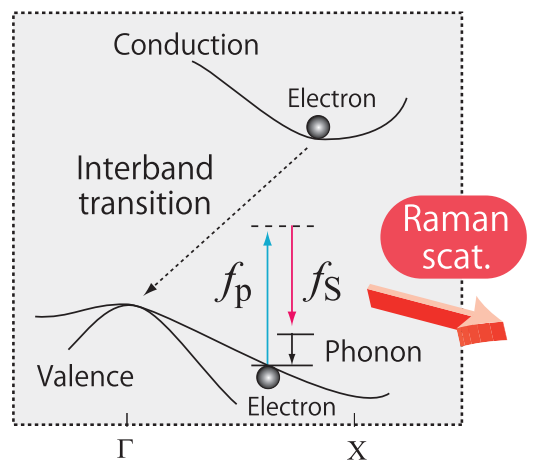

Fig. 1 Raman scattering with energy dispersion relation for silicon. The probability for interband transition is low due to the inconsistency of the wavevector.
なエンジニアリングが試みられたが，通常の半導体レー ザーと同等といえるレーザー光源は, 未だシリコンでは 実現していない。しかし，シリコンを用いてレーザー光 を発生させることの産業上の利益は計り知れず, シリコ ンレーザー開発は, 現在でもシリコンフォトニクスの中 心テーマである。本稿では, 誘導ラマン散乱現象を用い て, 唯一, バルクシリコンでレーザー発振を実現してい るラマンシリコンレーザーについて, 最近, 我々が実現 した極微小・超低しきい值デバイスを中心に解説す $ろ^{2)}$.

$$
\text { 2. ラマンシリコンレーザー }
$$

誘導ラマン散乱は, 3次の非線形効果として古くから 研究され，シリコンのラマン利得係数は非常に高いこと が知られていた が報告されており，ラマン増幅素子として有名なシリカ ファイバ $(0.01 \mathrm{~cm} / \mathrm{GW})$ よりも3〜4桁大きい. またシリ コン微細加工技術の進展により，2000年前後には，光を 強く閉じ込めることが可能なシリコン細線導波路が開発 され，シリコンフォトニクスは注目を浴び始めていた。 このような背景のもと, 2002年, シリコン細線導波路に 
おける誘導ラマン散乱を用いて光利得を得る手法が提案 された .この時の提案では, $1.9 \mathrm{~cm}$ の長さをもつ導波 路に, $500 \mathrm{~mW}$ も光を入れた時に $10 \mathrm{~dB}$ の光増幅が得ら れるというもので，これは一見すると実用性にそしいも のであったが、このデバイスの研究は活発に進められ た-9)。そ結果，2005年インテル社により，ファブリ ペロー型の共振器構造を用いた室温連続発振が報告さ $れ^{10)}$ ，世界初の全シリコンによるレーザーとして大きな 注目を集めた。

しかし，一般的にラマン散乱の確率はバンド間遷移の 確率よりも更に低いため, レーザ発振を起こすために は, $200 \mathrm{~mW}$ 以上の励起光パワーと $1 \mathrm{~cm}$ 以上の共振器長 が必要となった。さらに不都合なことに，強励起により 2光子吸収が発生して自由キャリアが細線中に生成され, 自由キャリア吸収損失がもたらされるため"11，これを除 去するために, シリコン細線導波路に沿って逆バイアス P-i-Nダイオード構造を付加する必要があった，高 $Q$ 值リ ング型共振器構造を用いて, 共振器損失を極限まで抑え ることが試みられたが, $20 \mathrm{~mW}$ までしい值を低減した 報告を最後に性能改善は進まなかった ${ }^{12}$.

ラマンシリコンレーザーは光励起型のレーザーであ り, 一般的な電流注入型の半導体レーザーと比べれば利 用範囲は制限されるが，いくつかの魅力的な利点を持 つ.たとえば, バンドギャップ以下の透明な波長全てで 動作可能なため, 全ての光通信波長帯において動作可能 である。また，カスケードレーザー発振を用いること で, 半導体レーザーの空白波長域となっている $2-4 \mu \mathrm{m}$ の波長を持つレーザー光も原理的には発生可能であ る ${ }^{13)}$.さらに，レーザー発振だけでなく，光回路に扔い て光増幅機能としても誘導ラマン散乱は利用可能であ る.これらの理由から, 小型で低しきい值動作するラマ ンシリコンレーザーが開発されれば，将来的に何らかの 形で応用製品に寄与する可能性は高いと思われる.

\section{3. ナノ共振器を用いた超小型・超低しきい值 ラマンシリコンレーザーの開発}

一般的に，レーザーのしきい值を下げるためには，高 いQ值と微小体積を持つ共振器により, 光と物質の相互 作用を増強する手法が有効である。 Fig. 2 に微小共振器 を用いたラマンシリコンレーザーの概念図を示す。誘導 ラマン散乱は, 励起光がシリコンの光学フォノンにより 散乱されて生じるストークスラマン光が非線形に増幅す る現象である。そのため、レーザー発振を起こすために は, 励起光とストークス散乱光の両方を強く閉じ込める $2 つ$ 高 $Q$ 值共振モード(Pump mode とStokes mode) が必 要となる。この点が, 通常の半導体レーザーと大きく異 なっている。また，その周波数差はシリコンの点に扔 ける光学フォノンエネルギーである15.6 THzに一致して いなければならない。ささらに，ラマン散乱確率が高くな るような電磁界分布を両者が持つことが望ましい。これ らの条件を高度に満たせば, 2 光子吸収に起因する自由 キャリア吸収にラマン利得が打ち勝ち、レーザー発振が
得られると原理的には期待できる。しかしながら，通 常, 共振器を小さくすると共振モードの $Q$ 值は下がるの

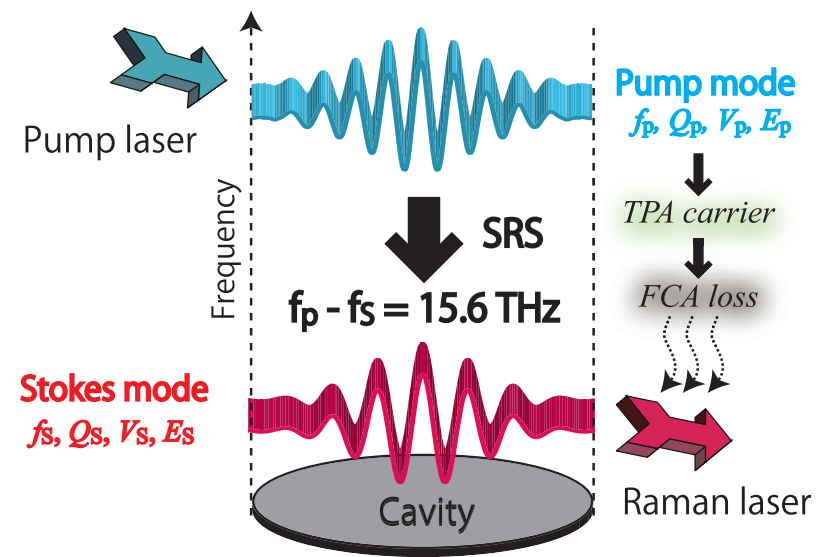

Fig. 2 Configuration of Raman silicon laser using a small cavity. Two nanocavity modes with $15.6 \mathrm{THz}$ spacing are required.

(a)
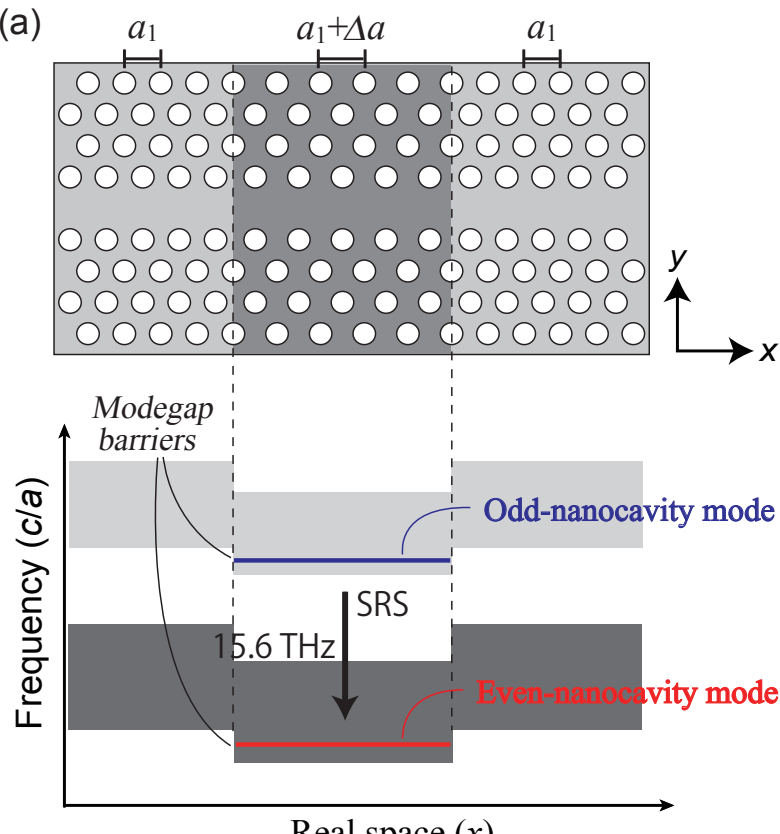

Real space $(x)$

(b)

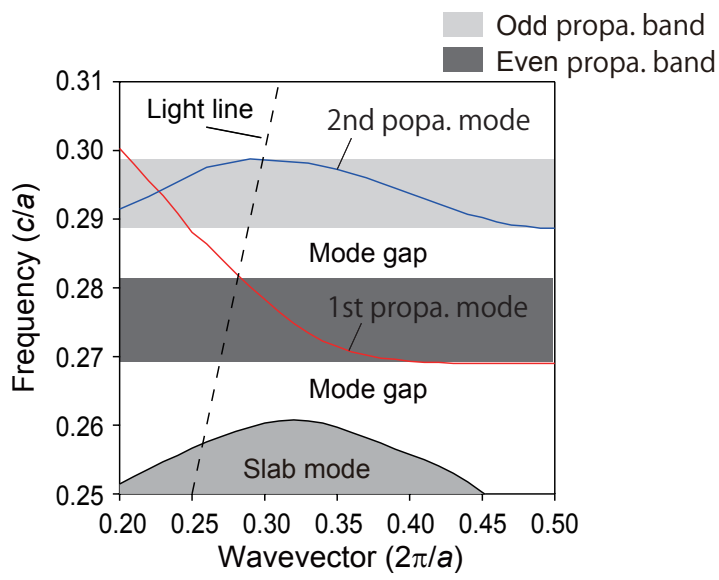

Fig. 3 (a) Schematic picture of heterostructure nanocavity in photonic crystal slab. The lattice constant at the center of the cavity is slightly larger in the $x$-direction. (b) Calculated band structure for the line-defect waveguide in $k$-space. 
で，2つの高 $Q$ 值共振モードを形成することは難しい. また共振モードの周波数が離散化されるため, 周波数差 を15.6 THzに一致させるのは容易でない. 当然, デバイ ス作製の難易度も高くなるので電磁界分布を制御するこ とは困難となり，微小デバイスゆえにラマンスペクトル 測定も困難となる。

このような背景のもと, 高 $Q$ 值と微小体積を併せ持つ 特長を有する2次元フォトニック結晶ナノ共振器 ${ }^{14-16)}$ や 導波路を用いたラマンシリコンレーザーの開発が複数の グループで検討された ${ }^{17-20)}$. しかし，上述の困難さから 実用的な構造の提案にはいたらず，発振に必要となる詳 細な条件もほとんど不明であった。 また, ナノ共振器か らの自然ラマン散乱の実験報告もなかった。我々は2009 年頃から, Fig. 3 (a)に示すへテロ構造ナノ共振器を用 いたラマンレーザー開発に取り組んだ。この共振器は 2005年に開発されたもので16), 線欠陥部分の導波可能周 波数が減少するように格子定数 $a$ を僅かに増加させ, ナ ノ共振モードを形成する。我々はこの共振器構造におい て, Fig. 3(b)のバンド図に示す第1導波モードに由来す るEven nanocavity modeを用いて，世界最高 $Q$ 值400万程 度を達成していた ${ }^{21)}$ 。そこで，この共振モードをStokes modeとして用いることとした。

レーザー開発において，まず一番の問題だったのは， Pump modeの選択である。それまでの提案では, 第1導 波モードに由来する高次の共振モードを用いていたが, 我々はへテロ構造ナノ共振器の高エネルギーモードを詳 細に調べた結果 ${ }^{22,23)}$ ，Fig. 3 (b) に示している第2導波 モードに由来するOdd nanocavity modeを用いることとし た。その理由は, Even nanocavity modeと同じ空間に局 在するモードであったこと， $Q$ 值 10 万以上が容易に得ら れたこと, 空気孔径を少し変えるだけでEven nanocavity modeとの周波数差を大きく調整できることを発見した からである ${ }^{24)}$ 。また, ほぼ同時期に, ナノ共振器からの ラマンスペクトル測定にも初めて成功して, 高 $Q$ 值ナノ 共振モードから増強ラマン散乱光が得られることを実証 した ${ }^{25)}$. その後, 2つのモードの周波数差を15.6 THzに 一致させたサンプルを作製して, 非常に強いラマン散乱 光の観測 ( $10^{-5}$ 程度の効率) に成功したが, レーザー発振 の観測には至らなかった ${ }^{26)}$. 連続励起下で, 2光子吸収

(a)

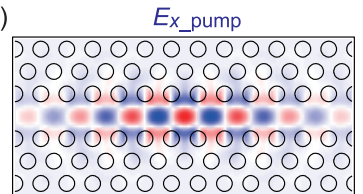

(b)

b000000000000 0000000000000
00000000000000 po00000000000

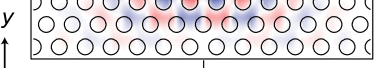

Fig. 4 Calculated electric field distributions for (a) the odd nanocavity mode and (b) the even nanocavity mode.
がもたらす自由キャリア吸収損失をラマン利得が上回る ためには，ラマン散乱確率が高くなるような電磁界分布 の組み合わせが必要不可欠だった。

Fig. 4に数值計算によるOdd nanocavity mode とEven nanocavity modeの電磁界分布 $E_{x}, E_{y}$ を示す，波長程度の 微小領域に閉じ込められた共振モードのため $x, y$ 両方の 偏光成分を持つが，由来する導波モードが異なるため， 空間対称性が正反対となっている。一方で良く見ると， たすき成分間 $\left(E_{x_{-} \text {pump }} \rightarrow E_{y_{-} \text {Stokes }}\right.$ または $\left.E_{y_{-} \text {pump }} \rightarrow E_{x_{-} \text {Stokes }}\right)$ では 同一の対称性を持ち，電磁界分布も類似していることが 分かる。そのため，たすき成分間での重なり積分が重要 となるような誘導ラマン散乱を利用できれば, レーザー 発振の可能性が高まる。そのためには，シリコンのラマ ンテンソルと結晶の方位が重要となる。

我々は, ナノ共振器を面方位が(001)のシリコン基板 上に作製しており，ナノ共振器を作製する方向として は，[100]方向か [110]方向が候補となる。詳細は割愛す るが，それぞれの方向における誘導ラマン散乱の大きさ は以下の積分に比例する ${ }^{27,28)}$.

$$
\begin{gathered}
\iiint_{\mathrm{Si}}\left|E_{x_{-} \text {Stokes }}^{*} E_{y_{-} \text {pump }}+E_{y_{-} \text {Stokes }}^{*} E_{x_{-} \text {pump }}\right|^{2} d x d y d z \\
\iiint_{\mathrm{Si}_{1}}\left|E_{x_{-} \text {Stokes }}^{*} E_{x_{-} \text {pump }}-E_{y_{-} \text {Stokes }}^{*} E_{y_{-} \text {pump }}\right|^{2} d x d y d z
\end{gathered}
$$

これらの式より，我々の共振器は [100]方向に作製する ことがベストと分かる。一方，仮に同一の空間対称性を 持つ高 $Q$ 值共振モード対を発見して，共振器を $[110]$ 方
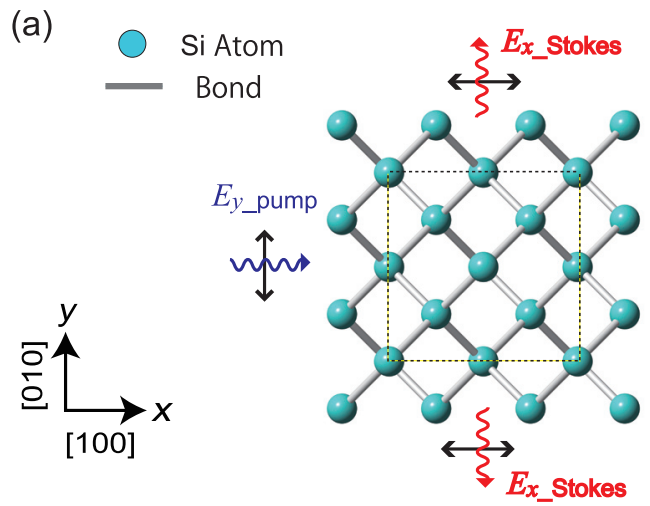

(b)
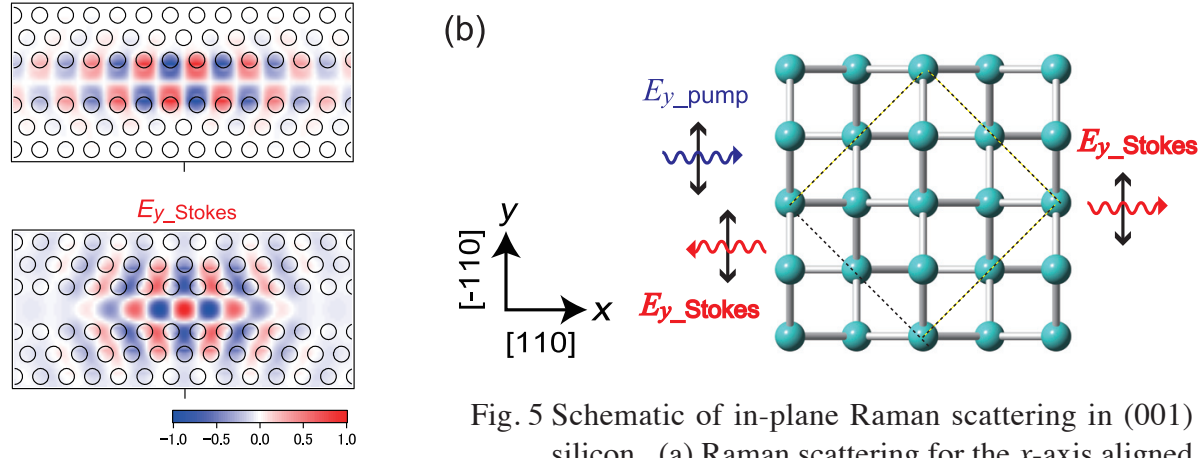

Fig. 5 Schematic of in-plane Raman scattering in (001) silicon. (a) Raman scattering for the $x$-axis aligned to [100]. Dotted lines show the outline of a unit cell. (b) Raman scattering for the $x$-axis aligned to [110]. 
向に作製したとしても，式(2)には負の項が関与してい るため, 我々のデバイス以上の重なりを得ることは困難 と予想される。

Fig. 5は, 式(1)と (2)のメカニズムを直観的に示して いる. Fig. 5 (a)のように入射光が[100]方向に進行して いる時，入射光の偏光に対してシリコン結晶の結合ボン ドのx-y面に対する射影は45度傾いており，面内へのス トークスラマン散乱光は入射光から 90 度回転した偏光を 持つ。この偏光回転により，たすき成分間の重なり積分 が式(1)では重要となる。一方で, Fig. 5 (b)のように入 射光の進行方向が $[110]$ 方向の時は, 入射光の偏光に対 して結合ボンドは平行または直交しており，面内へのラ マン散乱光は入射光と同じ偏光を持つ.つまり, 同一成 分間の重なり積分が重要となる.

\section{4. 超低しきい值ラマンシリコンレーザーの実証}

数年に及ぶ以上の基礎研究に基づいて，[100]方向と [110］方向に作製したナノ共振器に対して，顕微ラマン 測定を行った結果がFig. 6である。測定には, $a_{1}=410 \mathrm{~nm}, \Delta a=5 \mathrm{~nm}$ の $2 \mathrm{step} へ$ テ構造ナノ共振器を (a)

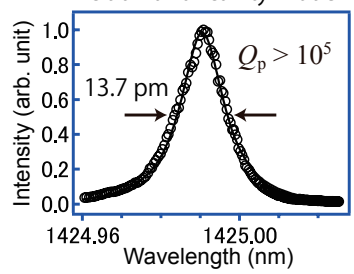

(b)

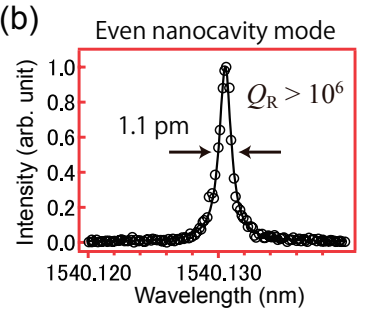

(c)

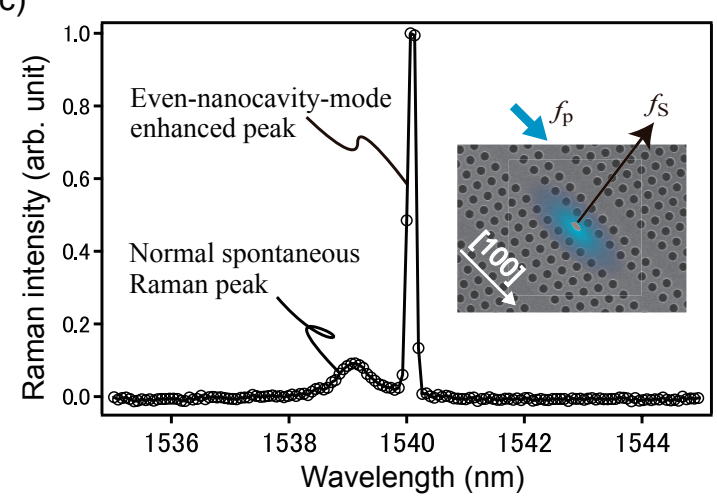

(d)

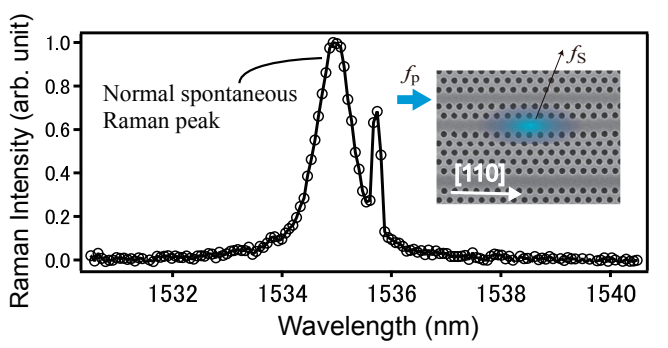

Fig. 6 Resonant spectra for (a) odd and (b) even nanocavity modes. (c) Raman spectrum for the [100] nanocavity, measured while pumping the odd nanocavity mode with $1 \mu \mathrm{W}$ input power. (d) Raman spectrum for the reference [110] nanocavity.
用いた. Fig. 6 (a)，（b)に示すように, Odd nanocavity $\operatorname{mode} の Q$ 值は10万以上, Even nanocavity modeの $Q$ 值 は 100 万以上が得られ，周波数差はほぼ $15.6 \mathrm{THz}$ に一致し ている. Fig. 6 (c)，（d）の挿入図は，作成したサンプル の電子顕微鏡像であり，3本の線欠陥のうち，中央の欠 陥がへテロ構造ナノ共振器, 上下の欠陥はナノ共振器に 励起光を送り达むための導波路である。本サンプルで は，ラマンスペクトル測定上の都合からラマン散乱光の 多くが垂直方向に放出されるようにデバイスを設計して ある.Fig. 6 (c)，（d）は，Odd nanocavity modeを波長可 変レーザー(Santec TSL-510) で励起したときの両者のラ マンスペクトルであり，自然ラマン散乱によるブロード なピークとEven nanocavity modeに共鳴したことによる シャープなピーク両方が明瞭に観測されている。自然ラ マンピークとEven nanocavity modeによるピークの離調 は両者で同程度 $(0.14 \mathrm{THz}$ 程度)であるが, 明らかに [100]方向に作製した共振器の方で，強い共鳴ピークが 得られており，その強度比は10倍以上に及ぶ。離調が小 さくなると，共鳴ピークの強度が強くなるが，[110]方 向に作製した共振器ではレーザー発振は観測されなかっ た。

Fig. 7が周波数差がほぼ15.6 THzに一致した共振器(離 調0.01 THz以下) を用いた時のレーザー発振の結果を示 している. Odd nanocavity modeの $Q$ 值は約 10 万, 波長

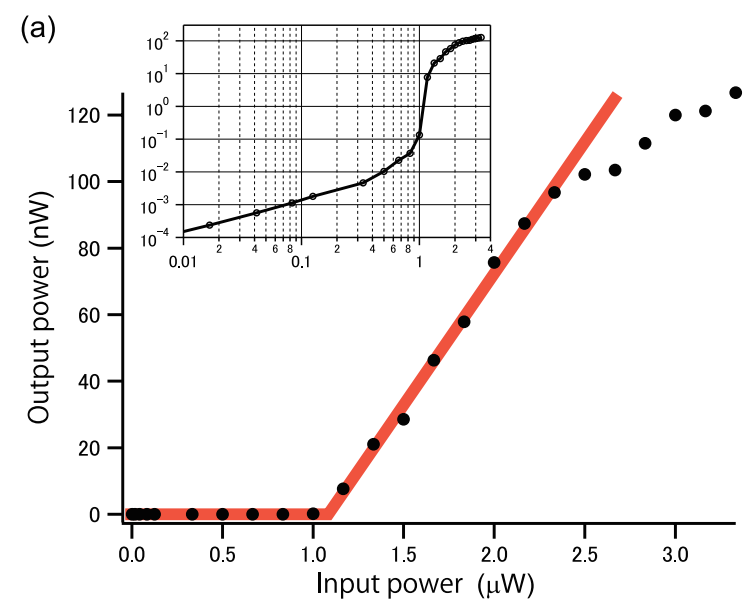

(b)

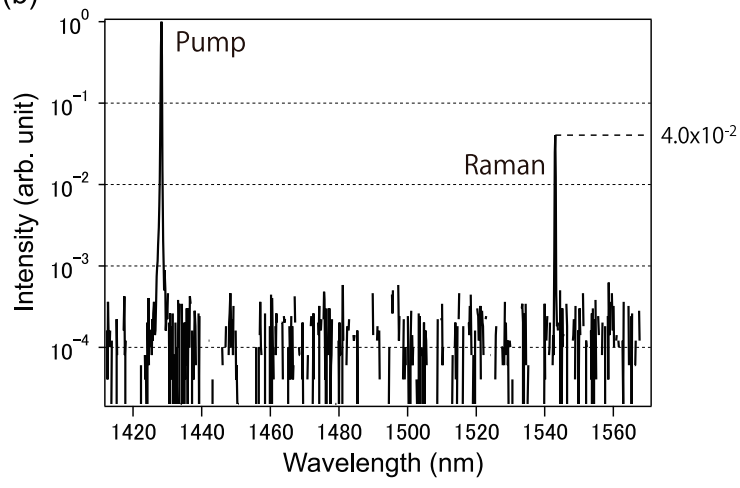

Fig. 7 (a) Laser output power as a function of pump power coupled into the nanocavity. Inset shows the log-log plot. (b) Full laser spectrum of total output including the pump wavelength at $3.0 \mu \mathrm{W}$ input. 
$1428 \mathrm{~nm}$, Even nanocavity modeの $Q$ 值は150万, 波 長 $1543 \mathrm{~nm}$ である。共振器への入射強度が約 $1 \mu \mathrm{W}$ に達した ところで明瞭なレーザー発振が確認されており, このし きい值は, 高 $Q$ リング共振器を用いたインテルのラマン レーザーの2万分の1である ${ }^{12)}$. ログプロットを見て分か るように，発振前後でラマン散乱光の生成効率に1000倍 以上の差があることがわかる。これは, 我々の知る限り ナノ共振器レーザーとしては最も大きな值であり, 直接 遷移型半導体をナノ共振器に埋め込んだナノレーザーの 振る舞いとは大きく異なっている ${ }^{29-31)}$. 発振時の微分効 率は8\%, Fig.7 (b) に示すように, エネルギー効率の最 大は $4 \%$ となり, 初めて作製したサンプルとしては良好 な特性が得られた。また，バルク $\mathrm{Si}$ のを利得材質に用 いていることから，デバイスは堅牢であり，測定を繰り 返すことによる性能劣化は見られていない，我々はごく 最近, Even nanocavity modeの $Q$ 值を900万まで増大する ことに成功しており, レーザー性能は, 今後さらに改善 可能と予想される. また, Fig. 3 (a)の高 $Q$ 值へテロ構造 ナノ共振器は, すべての通信波長带で実現されているた め ${ }^{32)}$, 今回は1.55 $\mu \mathrm{m}$ 帯でのレーザー発振を実証したが, 本デバイスは $1.3 \mu \mathrm{m}$ 帯でも作製可能と考えている.

\section{5. まとめ}

我々は, へテロ構造ナノ共振器に形成される異なる導 波モードに由来する2つのナノ共振器モードを用いて, ラマンシリコンレーザーの室温連続発振に成功した。デ バイスサイズ，消費エネルギーともにインテルのレー ザーの1万分の1以下であり， P-i-N構造は不要である。 メタルフリーという意味で, より純粋なラマンシリコン レーザーである。今後, しきい值をさらに下げることは 十分可能であり, $100 \mathrm{nW}$ レ゙ルの励起強度であれば, シリコンからの自然放出光でもレーザーの励起源として 利用可能と期待される.つまりシリコンLEDからの発光 を介した電流注入型のラマンシリコンレーザーが期待で きる。今回我々が発明したデバイスコンセプトは, さま ざまなナノ共振器構造に適用可能であると同時に, フォ トニック結晶導波路にも適用可能であり, 光増幅器の開 発までが今後の研究ターゲットになると予想され る33-37). 最後に, 本デバイスは， $Q$ 值 100 万以上を持つへ テロ構造ナノ共振器でなければ実現不可能であり, 10年 に及ぶナノ共振器の高 $Q$ 值化研究が 1 つの結実をみたも のであることを強調したい.

\section{謝 辞}

本研究は, 科学技術システム改革事業, 科学技術振興 機構さきがけ，科研費および光拠点，未来開拓研究プロ ジェクト等の支援を受けた。また，顕微ラマン測定系の 構築について，たくさんの専門家よりアドバイスをいた だいた。ここに深く感謝いたします。

\section{参考文献}

1) S. S. Iyer and Y.-H. Xie: Science 260 (1993) 40.

2) Y. Takahashi, Y. Inui, M. Chihara, T. Asano, R. Terawaki, and S. Noda: Nature (London) 498 (2013) 470.

3) R. Loudon: Adv. Phys. 13 (1964) 423.

4) J. M. Ralston and R. K. Chang: Phys. Rev. B 2 (1970) 1858.

5) R. Claps, D. Dimitropoulos, and B. Jalali: IEE Electron. 38 (2002) 1352.

6) B. Jalali and S. Fathpour: Journal of Lightwave Tech. 24 (2006) 4600.

7) A. Barkai, Y. Chetrit, O. Cohen, R. Cohen, N. Izhaky, M. Morse, O. Dosunmu, A. Liu, L. Liao, and M. Paniccia, et al.: Journal of Optical Networking 6 (2007) 25.

8) O. Boyraz and B. Jalali: Opt. Express 12 (2004) 5269.

9) H. Rong, A. Liu, R. Jones, O. Cohen, D. Hak, R. Nlcolaescu, A. Fang, and M. Paniccia: Nature (London) 433 (2005) 292.

10) H. Rong, R. Jones, A. Liu, O. Cohen, D. Hak, A. Fang, and M. Paniccia: Nature (London) 433 (2005) 725.

11) T. K. Liang, and H. K. Tsang: Appl. Phys. Lett. 84 (2004) 2745.

12) H. Rong, S. Xu, Y. Kuo, V. Sih, O. Cohen, O. Raday, and M. Paniccia: Nature Photon. 1 (2007) 232.

13) H. Rong, S. Xu, O. Cohen, O. Raday, M. Lee, V. Sih, and M. Paniccia: Nature Photon. 2 (2008) 170.

14) S. Noda, A. Chutinan, and M. Imada: Nature (London) 407 (2000) 608.

15) Y. Akahane, T. Asano, B. S. Song, and S. Noda: Nature (London) 425 (2003) 944.

16) B. S. Song, S. Noda, T. Asano, and Y. Akahane: Nature Mater. 4 (2005) 207.

17) X. Yang and C. W. Wong: Opt. Express 15 (2007) 4763.

18）高野仁路, 浅野卓, 野田進: 第54回春季応用物理学 会 29a-ZB-8 (2007)

19）篠森 直哉, 中山茂, 岩本 敏, 荒川 泰彦: 第57回春季応用 物理学会 20p-M-7 (2010).

20) X. Checoury, M. E. Kurdi, Z. Han, and P. Boucaud: Opt. Express 17 (2009) 3500.

21) Y. Taguchi, Y. Takahashi, Y. Sato, T. Asano, and S. Noda: Opt. Express 19 (2011) 11916.

22) Y. Takahashi, Y. Tanaka, H. Hagino, T. Asano, and S. Noda: Appl. Phys. Lett. 92 (2008) 241910.

23) Y. Takahashi, Y. Inui, M. Chihara, T. Asano, R. Terawaki, and S. Noda: Phys. Rev. B 88 (2013) 235313

24）千原賢大, 寺脇了, 高橋和, 浅野卓, 野田進: 第71回秋 季応用物理学会 16p-J-2 (2010).

25) Y. Takahashi, R. Terawaki, M. Chihara, T. Asano, and S. Noda: Quantum Electronics and Laser Science Conference (CLEO) QWC3 (2011)

26）千原賢大, 寺脇了, 高橋和, 浅野卓, 野田進：第72回秋 季応用物理学会 31p-ZR-2 (2011).

27）乾善貴, 高橋和, 浅野卓, 野田進: 第73回秋季応用物理 学会 14p-B1-6 (2012).

28) Y. Takahashi, Y. Inui, M. Chihara, T. Asano, R. Terawaki, and S. Noda: Nature 498 (2013) 470 Supplementary.

29) K. Nozaki, S. Kita, and T. Baba: Opt. Express 15 (2007) 7506.

30) M. Nomura, N. Kumagai, S. Iwamoto, Y. Ota, and Y. Arakawa: Nature Physics 6 (2010) 279.

31) K. Takeda, T. Sato, A. Shinya, K. Nozaki, W. Kobayashi, H. Taniyama, M. Notomi, K. Hasebe, T. Kakitsuka, and S. Matsuo: Nature Photon. 7 (2013) 569.

32) R. Terawaki, Y. Takahashi, M. Chihara, Y. Inui, and S. Noda: Opt. Express 20 (2012) 22743.

33) E. Kuramochi, M. Notomi, S. Mitsugi, A. Shinya, T. Tanabe, and T. Watanabe: Appl. Phys. Lett. 88 (2006) 041112.

34) M. Notomi, E. Kuramochi, and H. Taniyama: Opt. Express 16 (2008) 11095 .

35) T. Baba: Nature Photon. 2 (2008) 465

36) B. S. Song, S. B. Jeon, and S. Noda: Opt. Lett. 36 (2011) 91.

37) H. Sumikura, E. Kuramochi, H. Taniyama, and M. Notomi: Appl. Phys. Lett. 102 (2013) 231110. 


\section{$Q$ 值 $(Q$ factor $)$}

共振器が光を閉じ込める強さを表す無次元量. 英語の Qualityの頭文字に由来しており，英語では $Q$ factorと呼 ばれる。より一般には, 機械振動や電気共振回路の振動 状態の性能を表すためにも頻繁に使用される，Q值が高 い共振器は, 光を長く閉じ込めることが出来るので, 光 と物質の相互作用を高めることが可能となる。たとえ
ば，反射率の高いミラーで作った共振器ほど $Q$ 值が高い ことになり, 光は共振器内を何度も往復して共振器内の 媒質と何度も相互作用できる。 また， $Q$ 值が高い共振器 は，共振スペクトルの波長幅がシャープなため，高感度 センサー応用に適している。

(高橋 和)

\section{ヘテロ構造ナノ共振器 (Heterostructure nanocavity)}

2005年に報告されたナノ共振器構造で*, 非常に高い $Q$ 值を持つことを特徴とする。それまで報告されていた ナノ共振器の $Q$ 值は 10 万程度が最高であったが, この共 振器構造の発明により，1億を超えるナノ共振器構造の 設計も可能となった。ナノ共振器の $Q$ 值を上げるために は, 電磁界分布が共振器の長手方向に対して緩やかに変 化することが重要となる。それまでの共振器構造では, 共振器の端に空気孔を置いて空気との大きな屈折率変化
を用いて光を反射させて閉じ込めていた，一方、へテロ 構造ナノ共振器では共振器端に空気孔は無く, 格子定数 を中心だけ少し大きくしたことによるモードギャップ差 を利用して光を反射させている。このモードギャップ差 による光の反射により，緩やかに電磁界分布が変化し て，非常に高い $Q$ 值を実現した

(高橋 和)

*B. S. Song, S. Noda, T. Asano, and Y. Akahane: Nature Mater. 4 (2005) 207. 